49. Raghu G, Johnson WC, Lockhart D, Mageto Y. Treatment of idiopathic pulmonary fibrosis with a new antifibrotic agent, pirfenidone: results of a prospective, open-label phase II study. Am J Respir Crit Care Med 1999;159:1061-1069.

50. Lachner H, Urban C, Kerbl R, et al. Noncytotoxic drug therapy in children with unresectable desmoid tumors. Cancer 1997;80:334-340.

51. Maravilla KR, Bowen BC. Imaging of the peripheral nervous system: evaluation of peripheral neuropathy and plexopathy. AJNR 1998;19:1011-1023.
52. Ferner RE, Lucas JD, O'Doherty MJ, et al. Evaluation of 18fluorodeoxyglucose positron emission tomography (18FDG PET) in the detection of malignant peripheral nerve sheath tumours arising from within plexiform neurofibromas in neurofibromatosis 1. J Neurol Neurosurg Psychiatry 2000;68: 353-357.

53. Gill TM, Feinstein AR. A critical appraisal of the quality-oflife measurements. JAMA 1994;272:619-626.

54. Hays RD, Sherbourne C, Manzel E. The Rand 36-item health survey 1.0. Health Econ 1993;2:217-227.
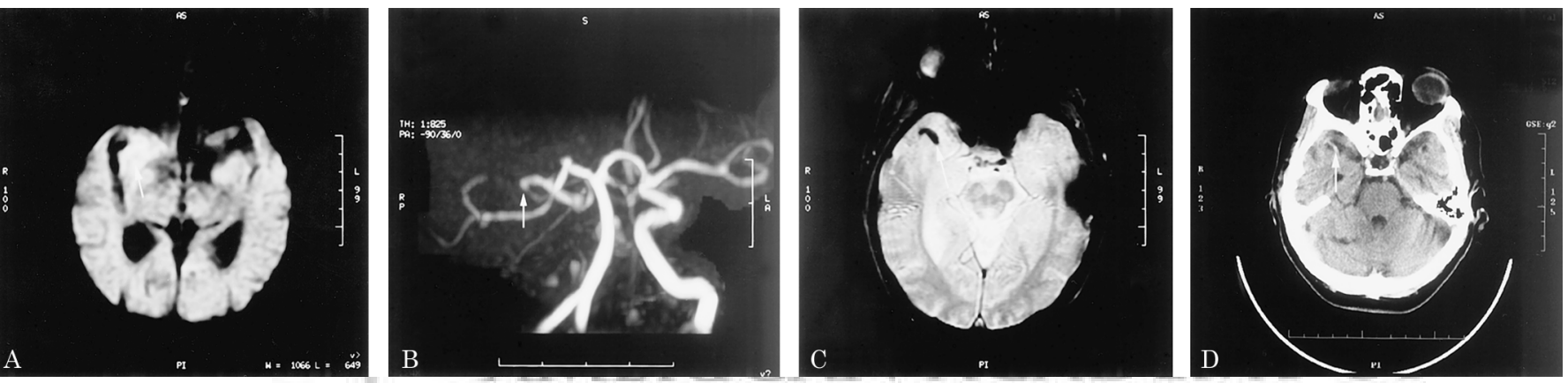

Figure. (A) Hyperintense region is seen in the right middle cerebral artery (MCA) territory on diffusion-weighted imaging compatible with an acute infarct (arrow). (B) MR angiography shows occlusion of the right internal carotid artery with partial cross-filling of the right MCA and signal loss at the right M1 segment (arrow). (C) GRE reveals the susceptibility artifact of acute thromboembolism in the right MCA (arrow). (D) Nonenhanced CT depicts a right hyperdense MCA sign (arrow).

\section{The hypointense MCA sign}

J.A. Chalela, MD, J.B. Haymore, RN, MS, ACNP,

M.A. Ezzeddine, MD, L.A. Davis, RN, MSN, S. Warach, MD, PhD, Bethesda, MD

A 74-year-old woman with history of hypertension and atrial fibrillation arrived at the hospital 20 minutes after a sudden onset of left hemiparesis. On examination, she was alert and oriented, had a right gaze preference, left homonymous hemianopia, left hemineglect, and dense left hemiparesis.

An emergent MRI and CT of the brain were obtained. An acute ischemic stroke was noted in the right middle cerebral artery (MCA) territory (figure, A). Intracranial MR angiography revealed a complete occlusion of the right internal carotid artery with partial cross-filling of the right MCA terminating at the right M1 (see figure, B) Gradient echo imaging (GRE) revealed a hypointense ovoid signal in the distal right sylvian fissure (see figure, C). A nonenhanced CT scan of the brain showed a right hyperdense MCA sign in the same territory (see figure, D).
The hyperdense MCA sign on CT is a well-characterized radiologic finding that may indicate acute vessel occlusion. Hypointense signals on GRE that are within vascular cisterns may also indicate acute thrombosis and should not be confused with acute hemorrhage, which may have similar characteristics. ${ }^{1}$ Defining features of the hypointense MCA sign on GRE include unilateral susceptibility changes that exceed the vessel diameter of the contralateral and susceptibility changes confined to vascular cisterns. Further evidence to support this conclusion is a corresponding vessel occlusion on MR angiography, homolateral perfusion deficit, and hyperdense MCA sign on CT. ${ }^{2}$ Distinguishing between the hypointense MCA sign indicating intraluminal occlusion and a hypointense region of intraparenchymal hemorrhage has important therapeutic implications in the acute stroke patient.

1. Linfante I, Llinas R, Caplan L, Warach S. MRI features of intracerebral hemorrhage within 2 hours from symptom onset. Stroke 1999;30:22632267.

2. Flacke S, Urbach H, Keller E, et al. Middle cerebral artery (MCA) susceptibility sign at susceptibility-based perfusion MR imaging: clinical importance and comparison with hyperdense MCA sign at CT. Radiology 2000;215:476-482. 


\section{Neurology}

The hypointense MCA sign

J. A. Chalela, J. B. Haymore, M. A. Ezzeddine, et al.

Neurology 2002;58;1470

DOI 10.1212/WNL.58.10.1470

\section{This information is current as of May 28, 2002}

\section{Updated Information \& Services}

\section{References}

Citations

Subspecialty Collections

Permissions \& Licensing

Reprints including high resolution figures, can be found at: http://n.neurology.org/content/58/10/1470.full

This article cites 2 articles, 1 of which you can access for free at: http://n.neurology.org/content/58/10/1470.full\#ref-list-1

This article has been cited by 5 HighWire-hosted articles: http://n.neurology.org/content/58/10/1470.full\#\#otherarticles

This article, along with others on similar topics, appears in the following collection(s):

Embolism

http://n.neurology.org/cgi/collection/embolism

Infarction

http://n.neurology.org/cgi/collection/infarction

MRI

http://n.neurology.org/cgi/collection/mri

Information about reproducing this article in parts (figures,tables) or in its entirety can be found online at:

http://www.neurology.org/about/about_the_journal\#permissions

Information about ordering reprints can be found online:

http://n.neurology.org/subscribers/advertise

Neurology ${ }^{\circledR}$ is the official journal of the American Academy of Neurology. Published continuously since 1951, it is now a weekly with 48 issues per year. Copyright. All rights reserved. Print ISSN: 0028-3878.

Online ISSN: 1526-632X.

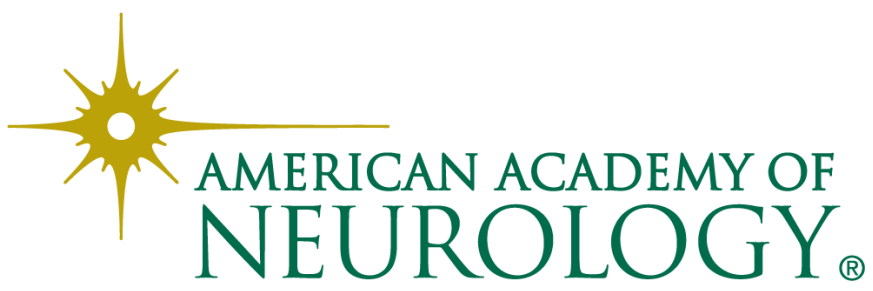

